\title{
Editorial: Applying psychology: A feitschrift for Dr. Elizabeth A. Dunne
}

\author{
John McCarthy ${ }^{1}$, Ethel Quayle ${ }^{1}$, Sue Aylwin ${ }^{1}$, \& Fiona Lyddy ${ }^{2}$ \\ 'Department of Applied Psychology, University College Cork \\ ${ }^{2}$ Department of Psychology, National University of Ireland, Maynooth
}

\begin{abstract}
This special issue of The Irish Journal of Psychology is dedicated to the memory of Dr. Elizabeth Dunne, our friend and colleague, and especially to her commitment to the application of psychology. It celebrates her particular contribution by surveying the variety of ways in which psychology is applied through, for example, practical problem solving, education, and advocacy. Applying psychology is a complex and often controversial practice; complex because most real world problems are multi-dimensional and intersubjectively defined; controversial because psychologists, like other professionals, carry with them their own values and perspectives. In this editorial, we sketch out some of the contributions Liz made in her working life, and present an overview of the 12 articles comprised within this special issue, and how they touch on Liz's interests and engage with the complexity of applying psychology.
\end{abstract}

\section{Introduction}

Liz (Elizabeth) Dunne was our friend and colleague. She worked up to a few days before her very premature death, and left behind a substantial body of work and some not yet finished. Having said our personal goodbyes, we undertook this project to acknowledge and celebrate her working life. Applied psychology was very important to Liz. She really believed in the power of education and psychology to change things for the better, and she acted on that in an impressive array of research, consultancy, and teaching projects.

Having completed a degree in psychology in University College Cork, and an MSc in Clinical Psychology in Trinity College, University of Dublin, Liz began her professional academic career at the Karolinska Institute in Stockholm, working there from 1972-1975 researching psychological and physiological aspects of the stress response. She returned to Ireland to lecture in University College Galway (1975-1977). She once told us (maybe more than once!) how much she enjoyed talking about 'Harlow agus a mhoncai' as Gaeilge during her job interview there. She moved from Galway to take up the lecturing position in University College Cork that she held from 1977. In her near 30 years in University College Cork, she lectured in all areas, from biological to organisational psychology, and supervised Masters and $\mathrm{PhD}$ students. She also carried 
out applied research in contexts from industrial safety to organisational identity, and was often invited to act as a consultant to organisations that became aware of her research and its relevance to them. In later years her research was concerned with health-related organisational issues such as the experiences of women suffering from Hepatitis $\mathrm{C}$ after blood transfusions and service users' experiences of mental health services.

Liz was an outstanding teacher and supervisor to many University College Cork students and will be remembered kindly. Whether teaching biological bases or social psychology, to major students or minor, she was deeply concerned that all students should have an excellent learning experience and that they would take some insights or values from applied psychology that would be helpful at some point in their lives. 'What's the point if it doesn't make a difference to them' would be her view. She also understood that the quality of a learning experience depends as much on the student's curiosity and readiness to work as on the teacher's approach. This made her a demanding teacher to whom those keen to learn responded fully. One of her students recalled when Liz died how she could start a lecture with the most ordinary examples or points and end up drawing out of those students the most interesting insights and moments of awareness. The student also recalled how Liz used her need for an oxygen mask during the lecture as an opportunity to teach and learn, while joking about it at the same time. Because she was such a great teacher, and a friend and support to many of her students, she has left a few generations of students who have been strongly influenced by her and who feel a great loyalty toward her. They learnt from her how important and powerful psychology could be and, even more so, how important and powerful relationships could be.

Liz will be known to many in Irish psychology and beyond for her commitment to applying the skills and understanding of psychology to try to help people in many areas. She was an applied psychologist through and through, hence the particular focus of this issue on applying psychology. In talking about her work as a psychologist and in doing it, she displayed a rich appreciation of the variety of stances available to psychologists trying to make psychology work for others and for society in general. One was an educational stance in which she saw her job as translating research into usable ideas and practices that she would then communicate to those who needed and could use those research insights. Sometimes the educational stance was not enough and she would become something of a facilitator or mediator, working at the coalface to tease out what the issues were and to work with the professionals, whose coalface it was, to try to develop appropriate interventions. In some contexts, particularly in the mental health area, applying psychology was a critical and political project for her in which she took an advocacy stance in the face of what she might have described in a calm moment as psychologically unhelpful treatment of people who were not in a good position to speak for themselves. In less calm moments she would have used far stronger language.

She worked for many years in the area of health and safety at work and published a book The psychology of working safely (Dunne, 2000) that is used by many health and safety practitioners in Irish industry and public service. The premise of that book, that safer working requires a better understanding among safety professionals of the psychology of human behaviour and cognition, along with her accessible style of writing, captures much of what applying psychology meant to Liz. It brought invitations to work on health and safety projects all over Ireland. Even when she wasn't able to travel some 
of psychology such as forensic psychology (Staunton, Hammond, \& Lambert, 2008; Taylor \& Quayle, 2008; Thompson, Townsley, \& Pease, 2008) in which she was not active herself, but which she enjoyed discussing with colleagues. Liz was a voracious reader and had interests well beyond those she had time to explore. One of her great fascinations was Irish politics. There might have been a book on the psychology of Irish politics in retirement. Another was religion and spirituality, about which she had great conversations with our former colleague Peter Hampson on his regular visits to Cork and to Liz. She would have been delighted to see Pete's paper (Hampson, 2008) in an issue on applying psychology. Her interest in religion included a practical engagement with Bhuddist spirituality and psychology, reflected here in Peter Malinowski's paper on mindfulness (Malinowski, 2008).

We are very pleased with the outcome, and hope you enjoy reading the papers, and think of Liz applying psychology as you do. We want to thank all of those who contributed. There were many more than those published here and we want to thank all of them. We want especially to thank our reviewers who read carefully and commented considerately. Many of the authors and reviewers will now be familiar with Julie Pujol who works in the office in the Department of Applied Psychology at University College Cork, and who has done all of the hard work of managing papers, reviews, contacting authors and reviewers. Without her this would have been a much harder job. Finally, we want to thank Drs. Fiona Lyddy and Christopher Alan Lewis of The Irish Journal of Psychology for their receptiveness to the idea of this special issue, and extensive help in developing it.

Our interest in promoting this special issue is to recognise Liz's work and to mark the value of applying psychology. Liz would probably be embarrassed by the former and fully approve of the latter.

\section{References}

de Búrca, S. (2008). Alignment and variation in managerial and professional perceptions of purpose, leadership roles and outcomes in a healthcare organisation's change programme. Irish Journal of Psychology, 29, 45-59.

Dunne, E.A. (2000). The psychology of working safely. Dublin: Blackhall Publishing.

Dunne, E.A. (2006). The views of adult users of the public sector mental health services: Report of a survey for the mental health commission. Dublin: Mental Health Commission.

Dunne, E.A., \& Quayle, E. (2001). The impact of iatrogenically acquired hepatitis C infection on the well-being and relationships of a group of Irish women. Journal of Health Psychology, 6, 679-692.

Dunne, E.A., \& Quayle, E. (2002). Pattern and process in disclosure of health status by women with iatrogenically acquired hepatitis C. Journal of Health Psychology, 7, 565-582.

Gormley, M., Walsh, T., \& Fuller, R. (2008). Risks in the driving of emergency service vehicles. Irish Journal of Psychology, 29, 7-18.

Hampson, P.J. (2008). Psychology and religion: Continuing an interrupted conversation. Irish Journal of Psychology, 29, 139-154.

Hickey, A.M., McGee, H.M., Smith, M., \& Murray, F. (2008). Iatrogenesis and hepatitis 
C infection: Implications for well-being. Irish Journal of Psychology, 29, 19-33. Malinowski, P. (2008). Mindfulness as psychological dimension: Concepts and applications. Irish Journal of Psychology, 29, 155-166.

Moane, G. (2008). Applying psychology in contexts of oppression and marginalisation: Liberation, psychology, wellness, and social justice. Irish Journal of Psychology, 29, 89-101.

Montgomery, A. J., Peeters, M.C.W., Schaufeli, W.B., \& Panagopoulou, E.P. (2008). Crossover and work-home interference. Irish Journal of Psychology, 29, 61-76.

Reid, T., \& Quayle, E. (2008). A salutogenic perspective on occupational health. Irish Journal of Psychology, 29, 35-44.

Staunton, C., Hammond, S., \& Lambert, S. (2008). Applying knowledge of female sexual arousal to the forensic context. Irish Journal of Psychology, 29, 103-117.

Sullivan, P. (2008). Empathy and applied psychology; Dunne's (2006) report on the 'Views of adult users of the public sector mental health services'. Irish Journal of Psychology, 29, 77-88.

Taylor, M., \& Quayle, E. (2008). Criminogenic qualities of the Internet in the collection and distribution of abuse images of children. Irish Journal of Psychology, 29, 119-130.

Thompson, S., Townsley, M., \& Pease, K. (2008). Repeat burglary victimisation: Analysis of a partial failure. Irish Journal of Psychology, 29, 131-139. 